\title{
The expression of P-gp in leukemia cells is associated with cross-resistance to protein $\mathrm{N}$-glycosylation inhibitor tunicamycin
}

\author{
Lucia Pavlikova ${ }^{1}$, Mario Seres $^{1}$, Denisa Imrichova ${ }^{1}$, Milan Hano ${ }^{1}$, Andrej Rusnak ${ }^{1}$, Martina \\ Zamorova $^{2}$, Jaroslav Katrlik ${ }^{2}$, Albert Breier ${ }^{3}$ and Zdena Sulova ${ }^{1}$ \\ ${ }^{1}$ Institute of Molecular Physiology and Genetics, Slovak Academy of Sciences, Dubravska cesta 9, 84005 Bratislava, Slovak \\ Republic \\ ${ }^{2}$ Institute of Chemistry, Slovak Academy of Sciences, Dubravska cesta 9, 84538 Bratislava, Slovak Republic \\ ${ }^{3}$ Institute of Biochemistry and Microbiology, Faculty of Chemical and Food Technology, Slovak University of Technology, \\ Radlinskeho 9, 81237 Bratislava, Slovak Republic
}

\begin{abstract}
In P-gp-positive cell variants obtained from L1210 cells either by selection with vincristine (L1210/R) or by transfection with the human gene encoding P-gp (L1210/T), we have previously described cross-resistance to tunicamycin (TNM), a protein $\mathrm{N}$-glycosylation inhibitor. Here we studied whether this cross-resistance also underlies P-gp-positive variants of human acute myeloid leukemia cells (AML) derived from SKM-1 and MOLM-13 cells (SKM-1/VCR, SKM-1/LEN, MOLM-13/ VCR) by selection with vincristine (VCR) and lenalidomide (LEN). While SKM-1/LEN cells were P-gp positive, no P-gp was detected in MOLM-13/LEN cells. P-gp-positive cells could be repeatedly passaged in medium containing TNM. In contrast, more than $90 \%$ of P-gp-negative cells were entering and progressing through cell death mechanisms after the third passage in medium containing TNM. Combined apoptosis/necrosis cell death was detected in L1210 cells after exposure to TNM. Passaging of P-gp-negative AML cells in medium containing TNM induced preferentially apoptosis. Damage to P-gp-negative cells induced with TNM was associated with arrest in the G1 phase of the cell cycle. P-gp-positive leukemia cells differed from P-gp-negative cells in the composition of plasma membrane glycoproteins, which we monitored with the aid of different lectins. The application of TNM to cells induced additional changes in membrane-linked glycosides.
\end{abstract}

Key words: Leukemia cell lines - P-glycoprotein - Tunicamycin resistance - Apoptosis/necrosis detection - Lectins - Cell surface sugars

\begin{abstract}
Abbreviations: AML, acute myeloid leukemia; $\mathrm{CB}$, cacodylate buffer; cisPt, cisplatin; ConA, concanavalin A; DOX, doxorubicin; FAV, fluorescein isothiocyanate-labeled annexin V; LEN, lenalidomide; MDR, multidrug resistance; $M D R 1$, gene encoding P-gp; MRP1, multidrug resistance associated protein; MRP1, gene encoding MRP1; MTX, mitoxantrone; PBS, phosphate-buffered saline; PBST, PBS supplemented with $0.05 \%$ Tween 20; P-gp, P-glycoprotein, PI, propidium iodide; SNA, Sambucus nigra agglutinin; TNM, tunicamycin; VCR, vincristine; WGA, wheat germ agglutinin.
\end{abstract}

Correspondence to: Zdena Sulova, Institute of Molecular Physiology and Genetics, Slovak Academy of Sciences Dubravska cesta 9 , 84005 Bratislava, Slovak Republic

E-mail: zdena.sulova@savba.sk

Albert Breier, Institute of Biochemistry and Microbiology, Faculty of Chemical and Food Technology, Slovak University of Technology, Radlinskeho 9, 81237 Bratislava, Slovak Republic

E-mail: albert.breier@stuba.sk 


\section{Introduction}

Overexpression of P-glycoprotein (P-gp) in leukemia cells is a major molecular cause of multidrug resistance (MDR) development (Stavrovskaya et al. 1998; Andersen et al. 2015b). Expression of P-gp may be responsible for the attenuation of blood malignancies chemotherapy effectiveness (Messingerova et al. 2015b). P-gp is a plasma membrane efflux pump, the $\mathrm{ABCB} 1$ member of the $\mathrm{ABC}$ transporter family with broad substrate specificity (Li et al. 2010). When expressed in leukemia cells, P-gp decreases cell sensitivity to drugs that are P-gp substrates up to several hundred times (Breier et al. 2005). In addition to this generally accepted role as a drug transporter, $\mathrm{P}$-gp seems to be active as a regulatory protein with antiapoptotic effects, and this additional role is independent of its transport function (Pallis and Russell 2000; Ruefli 2003; Breier et al. 2013). The main evidence for this assumption is the fact that a transport-defective P-gp mutant expressed in CEM lymphoma cells decreases apoptosis progression induced by vincristine (VCR) (Tainton et al. 2004). Moreover, we have described less pronounced apoptosis progression induced by cisplatin (cisPt, not a P-gp substrate) in two P-gp-positive mouse leukemia cell variants, obtained either by selection with VCR (L1210/R) or by transfection with the human gene encoding P-gp (L1210/T) when compared with P-gp-negative parental L1210 cells (Gibalova et al. 2009, 2012). This additional role enables P-gp to reduce cell sensitivity to some drugs that are not P-gp substrates up to several times (Messingerova et al. 2016).

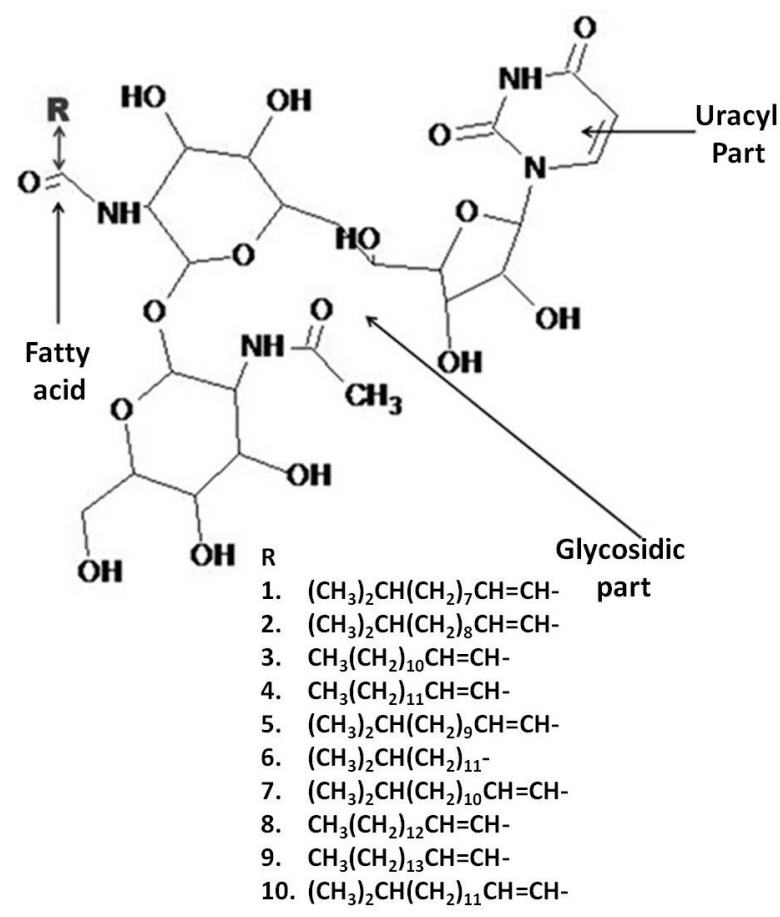

Oligo- and polysaccharide contents are altered by P-gp overexpression in L1210 cells (Fiala et al. 2003). This leads to differences in protein glycosylation between P-gp-positive and -negative cells (reviewed in Breier et al. 2005, 2013). Consistent with this, overexpression of P-gp in leukemia cells leads to large-scale remodeling of the cell surface glycosides that can be detected by several lectins (Molnar et al. 2009; Sulova et al. 2009, 2010; Bubencikova et al. 2012). Moreover, aberrant cell surface sialylation was described in MDR HL60 cells (Ma et al. 2015). These changes include alterations to the glycosylation of proteins other than P-gp (Sulova et al. 2009, 2010; Bubencikova et al. 2012). Differences in regulation of protein glycosylation could be associated with P-gp overexpression because tunicamycin (TNM, an inhibitor of protein $\mathrm{N}$-glycosylation) induces much less pronounced cell death in P-gp-positive L1210/R and L1210/T than P-gp-negative L1210 cells (Seres et al. 2011), i.e., both P-gp-positive cell lines are resistant to TNM. While TNM protects P-gp against glycosylation, an unglycosylated P-gp molecular variant $(145 \mathrm{kDa})$ that is localized in the plasma membrane exerts P-gp efflux activity, as measured using a calcein-AM retention assay (for details, see Seres et al. 2011).

TNM induces endoplasmic reticulum stress via inhibition of protein $\mathrm{N}$-glycosylation in the endoplasmic reticulum, which is part of the cell's protein quality control mechanisms (Lamriben et al. 2016). Its mechanism of action is based on inhibition of $\mathrm{N}$-acetyl glucosamine transfer from UDP$\mathrm{N}$-acetyl glucosamine to dolichol phosphate (Heifetz et al. 1979) attached to the inner side of the endoplasmic reticulum

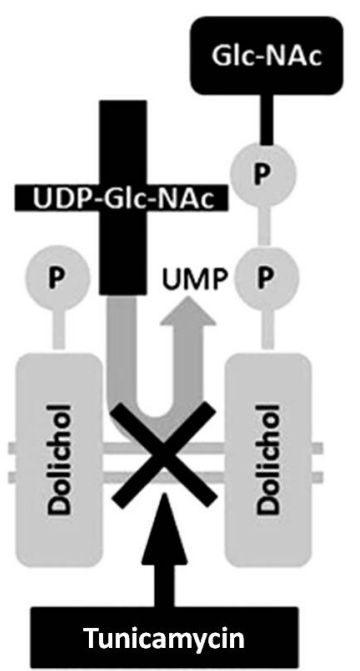

Figure 1. Tunicamycin chemical structure and mechanism of its inhibitory action. Tunicamycin is blocking the transfer of $\mathrm{N}$-acetylglucosamine-phosphate (Glc-NAc-P) from $\mathrm{N}$-acetylglucosamine-uracil diphosphate (UDP-Glc-NAc) to dolichol phosphate, which is integrated in internal leaflet of endoplasmic reticulum membrane phospholipid bilayer. This represents a first step of glycoside core synthesis. After synthesis of glycoside core it will be transferred from dolichol phosphate to amino group of asparagine residue of respective protein. UMP, uracyl monophosphate. 
membrane (Fig. 1), which is the first step of oligosaccharide core synthesis. Verapamil, a P-gp inhibitor (Colabufo et al. 2010), is not able to eliminate resistance of L1210/R and L1210/T cells to TNM (Seres et al. 2011). Therefore, resistance of both P-gp-positive L1210 cell variants seems to be unrelated to P-glycoprotein transport activity.

Thapsigargin, an inhibitor of sarcoplasmic reticulum $\mathrm{Ca}^{2+}$-pumps (Andersen et al. 2015a), reduces $\mathrm{N}$-glycosylation of proteins in the endoplasmic reticulum due to depletion of sarcoplasmic reticulum calcium ions, which are necessary ligands of calcium-dependent lectins of this organelle (calsequestrin and calreticulin) (Michalak et al. 2009). Thus, thapsigargin is another stressor of endoplasmic reticulum (Jipu et al. 2012). Interestingly, induction of endoplasmic reticulum stress in P-gp-positive variants of L1210 cells by thapsigargin leads to the presence of P-gp in unglycosylated form (Seres et al. 2010), similar to what is observed under treatment with TNM.

Thus, expression of P-gp in L1210/R and L1210/T cells induces additional cellular resistance to TNM that is independent of P-gp transport activity. In the present paper, we studied whether this resistance occurs in other P-gp-positive leukemia cell lines. P-gp-positive variants, SKM-1/VCR, SKM-1/LEN, and MOLM-13/VCR, which were obtained by selection of parental human acute myeloid leukemia cells SKM-1 and MOLM-13 with VCR and lenalidomide (LEN), were established in our previous paper (Imrichova et al. 2015). In contrast to SKM-1 cells, selection of MOLM-13 cells with LEN did not induce expression of P-gp (Imrichova et al. 2015). In the present paper, the sensitivity to TNM of P-gp-positive and P-gp-negative variants of SKM-1 and MOLM-13 cells were compared.

\section{Materials and Methods}

\section{Cell culture conditions}

The following cell variants were used in this study:

P-gp-negative cells obtained from Deutsche Sammlung von Mikroorganismen und Zellkulturen GmbH, (DSMZ Germany):

- Murine lymphocytic leukemia L1210 (ACC 123);

- Human acute myeloid leukemia SKM-1 (ACC 547);

- Human acute myeloid leukemia MOLM-13 (ACC 554);

- MOLM-13/LEN, obtained by culturing in media with stepwise increasing concentrations of LEN (Celgene, USA) (Imrichova et al. 2014, 2015)

P-gp-positive cell variants:

- L1210/R and L1210/T, obtained either by cultivation in stepwise-increasing concentrations of VCR (Polekova et al. 1992) or by transfection with a retrovirus encoding human P-gp (Sulova et al. 2010); the retrovirus was
pHaMDRwt (Addgene product 10957 USA), which contains the full-length P-gp cDNA (Pastan et al. 1988);

- SKM-1/VCR and SKM-1/LEN, obtained by culturing in media with stepwise-increasing concentrations of VCR (Sigma Aldrich, USA) and LEN (Imrichova et al. 2014, 2015);

- MOLM-13/VCR, obtained by culturing in media with stepwise-increasing concentrations of VCR (Imrichova et al. 2014, 2015).

All variants of L1210 were cultured in RPMI 1640 medium (GE Healthcare) containing 4\% fetal bovine serum (Biotech, SR) and $1 \mu \mathrm{g} / \mathrm{ml}$ of gentamicin (Gibco, USA) at $37^{\circ} \mathrm{C}$ in a humidified atmosphere containing $5 \% \mathrm{CO}_{2}$. L1210/T cells were cultivated in the presence of $1200 \mu \mathrm{g} / \mathrm{ml}$ antibiotic G418 (Invitrogen, USA). All variants of SKM-1 and MOLM-13 cells were grown in RPMI 1640 medium containing 12\% fetal bovine serum, 100,000 units/l of penicillin and $50 \mathrm{mg} / \mathrm{l}$ of streptomycin (both purchased from Sigma Aldrich) in a humified atmosphere containing $5 \% \mathrm{CO}_{2}$ at $37^{\circ} \mathrm{C}$ for two days.

All cell variants were passaged 1, 2 and 3 times (each passage was lasting two days) in the absence or presence of TNM $(0.1 \mu \mathrm{mol} / \mathrm{l}$, Sigma Aldrich USA).

\section{Effect of VCR, mitoxantrone (MTX), doxorubicin (DOX) and cisPt on the viability of drug-sensitive and -resistant variants of SKM-1 and MOLM-13 cells}

P-gp-negative and P-gp-positive variants of L1210, SKM-1 and MOLM- 13 cells $\left(5 \times 10^{4}\right.$ cells/well) were cultured with or without VCR (0-250 nmol/l), MTX (0-250 nmol/l), DOX $(0-250 \mathrm{nmol} / \mathrm{l})$ and cisPt $(0-15 \mu \mathrm{mol} / \mathrm{l})$ in $96-$ well cell culture plates. DOX, VCR, cisPt and MTX were added directly to $200 \mu \mathrm{l}$ of the culture medium. After 48 hours, cell viability was assessed using the MTT assay (Gerlier and Thomasset 1986), which was performed by adding MTT [3-(4,5-dimethylthiazol-2-yl)-2,5 diphenyltetrazolium bromide] to a final concentration of $0.25 \mathrm{mg} / \mathrm{ml}$ per well. The cells were then incubated with MTT for 2 hours. Next, the plates were centrifuged at 2,500 rpm for $15 \mathrm{~min}$, and the cell sediment was extracted using dimethyl sulfoxide. The absorbance at $540 \mathrm{~nm}$ was measured using a Universal Microplate Spectrophotometer mQuant (BioTek Instruments, Inc. USA). The $\mathrm{IC}_{50}$ values were obtained by fitting dose-response curves according to the following exponential decay equation (Eq. 1) using non-linear regression (Kupsakova et al. 2004):

$$
\mathrm{N}=100 \% \times \exp \left[\ln (0.5) \times\left(\mathrm{c} / \mathrm{IC}_{50}\right)\right]
$$

where $\mathrm{N}$ is the percentage of viable cells present after cultivation in the presence of drugs at concentration $c$ relative to that of control cells grown in the absence of a drug. The $\mathrm{IC}_{50}$ is the concentration of a substance when $\mathrm{N}=50 \% . \mathrm{IC}_{50}$ values were calculated from three independent measure- 
ments. The significance of differences was analyzed using unpaired Student's $t$-test.

\section{Determination of MDR1 and MRP1 gene expression in sensitive and resistant cells}

Total RNA from susceptible and drug-resistant SKM-1 and MOLM-13 cell lines was isolated using Trizol Reagent (Life Technology, Slovakia) according to the manufacturer's instructions. Reverse transcription was performed with $2 \mu \mathrm{g}$ of DNase I (Thermo Scientific, Germany)-treated RNA and the RevertAidTM H Minus First-Strand cDNA Synthesis Kit (Thermo Scientific, Germany) according to the manufacturer's protocol. PCR was performed in a total volume of $25 \mu \mathrm{l}$ using a PCR kit according to the manufacturer's protocol (Thermo Scientific, Germany). Expression of GAPDH was used as an internal standard. After treating the samples at $94^{\circ} \mathrm{C}$ for $3 \mathrm{~min}$ to inactivate the reverse transcriptase, the samples were subjected to 30 cycles of $95^{\circ} \mathrm{C}$ for $30 \mathrm{~s}$ followed by $57^{\circ} \mathrm{C}$ for $30 \mathrm{~s}$ for $G A P D H$ and $M D R 1$ or by $57.2^{\circ} \mathrm{C}$ for $30 \mathrm{~s}$ for $M R P 1$ and ending with $72^{\circ} \mathrm{C}$ for $90 \mathrm{~s}$, and a final extension of $72^{\circ} \mathrm{C}$ for $10 \mathrm{~min}$. The PCR products were separated in a $1.5 \%$ agarose gel (Invitrogen, Life Technology, Slovakia) and visualized using GelRedTM nucleic acid gel stain (Thermo Scientific, Germany). Gels were stained, and the bands were quantified using the Typhoon 9210 imaging system (GE Healthcare, USA). The data were expressed as the relative level of each mRNA normalized to that of $\beta$-actin. Statistical significance was analyzed using unpaired Student's $t$-test.

The primer sequences used in this study were as follows: GAPDH: 5'-AAC TTT GTC AAG CTC ATT TCC-3' and 5'-GCA GCG AAC TTT ATT GAT GGT-3', which produced a 267 bp product; for human MDR1': 5'-AAG TTG TAT ATG GTG GTG GGA ACT-3' and 5'-AAT TTT GTC ACC AAT TCC TTC ATT-3', which produced a 429-bp product; for mouse MDR1: 5' -AGG TAG AGA CAC GTG AGG TCG-3 and 5'-CAG CCA ACC TGC ATA ACG-3', which produced a 453-bp product; for human MRP1: 5'-AGA AGT CTG GAC GTC CCT G-3' and 5'-ACA CCA AGC CGG CGT CTT T-3', which produced a 404 bp product; for mouse $M R P 1$ : 5'-GAA ACC AAA CTA AAA GGA AGC AAA-3' and 5'- CAC TGA CAT AAC AAG GAC AGG AAC-3', which produced a 417bp product.

\section{Measurement of cell death induced by TNM}

Cells after passaging were harvested and used for estimation of cell death. The proportions of apoptotic and necrotic cells were then detected using a fluorescein isothiocyanate-labeled annexin V (FAV) and propidium iodide (PI) kit (Calbiochem, USA). According to the procedure described by the manufacturer, the cells were washed twice with phosphate-buffered saline (PBS, Sigma-Aldrich USA) and gently re-suspended in binding buffer (obtained from the manufacturer) containing $0.5 \mu \mathrm{g} / \mathrm{ml} \mathrm{FAV}$. The mixture was then incubated in the dark at room temperature for $15 \mathrm{~min}$ and centrifuged $(2,500 \mathrm{rpm}$, $15 \mathrm{~min}$ ). The resulting sediments were re-suspended in binding buffer, the PI (final concentration $0.6 \mu \mathrm{g} / \mathrm{ml}$ ) was added to each sample, and the samples were analyzed by flow cytometry using an Accuri C6 flow cytometer (BD Bioscience, USA). In this assay, the viability of cells was evaluated as follows: i. Cells not stained by both FAV and PI represented viable cells; ii. Cells stained by FAV or PI were considered apoptotic or necrotic cells, respectively; iii. Cells stained by both FAV and PI were fully damaged death cells in the late phases of apoptosis or necrosis.

\section{Light and electron microscopy}

The morphology of cells after passaging was observed under a light microscope (Axiovert 40C, Carl Zeiss, Germany) directly in the cultivation plate and after sample preparation, the cell ultrastructure was observed under an electron microscope (JEM-1200 EX, JEOL, Japan). Preparation of samples for electron microscopy: After cultivation, passaging cells were centrifuged at $1000 \times g$ for $3 \mathrm{~min}$, washed in PBS and fixed with $2 \%$ glutaraldehyde in $0.1 \mathrm{~mol} / \mathrm{l}$ sodium cacodylate buffer (CB) at $\mathrm{pH} 7.2$ for $60 \mathrm{~min}$. After fixation, cells were centrifuged at $1000 \times g$ for $3 \mathrm{~min}$ to form sediment. The specimen was then washed 3 times for $7 \mathrm{~min}$ with $\mathrm{CB}$ and postfixed with $1 \%$ osmium tetroxide in $\mathrm{CB}$ for $60 \mathrm{~min}$. The samples were rinsed in $\mathrm{H}_{2} \mathrm{O}$, stained overnight with $2 \%$ uranyl acetate, dehydrated in increasing concentrations of ethanol, cleared in propylene oxide and embedded in Durcupan. Ultrathin sections were cut with a microtome Porter-Blum MT2 and stained with lead citrate.

\section{Effect of cell cultivation in the presence of TNM on \\ $P$-gp-negative and $P$-g-positive cells cycling}

Cells $\left(1 \times 10^{6}\right.$ cells per $\left.\mathrm{ml}\right)$ after 24 or 48 hours of cultivation in the presence of TNM $(0.1 \mu \mathrm{mol} / \mathrm{l})$ were washed with PBS, resuspended in $0.05 \%$ Triton X-100 (Sigma-Aldrich USA) dissolved in PBS that contained $0.1 \mathrm{mg} / \mathrm{ml}$ RNase A (ThermoFisher Scientific, Germany) and incubated at $37^{\circ} \mathrm{C}$ for $20 \mathrm{~min}$. The final mixtures were cooled on ice for $10 \mathrm{~min}$, and PI $(40 \mu \mathrm{g} / \mathrm{ml})$ was added to the samples, which were then incubated on ice for an additional $30 \mathrm{~min}$. Finally, for each sample, PI fluorescence was monitored using a Accuri C6 flow cytometer (BD Bioscience, USA).

\section{Detection of FITC-labeled lectins binding to the surface of $P$-gp-positive and-negative cells after cultivation in the presence or absence of TNM}

Cells $\left(1 \times 10^{6}\right.$ cells per $\left.\mathrm{ml}\right)$ after 48 hours of cultivation in the presence of TNM $(0.1 \mu \mathrm{mol} / \mathrm{l})$ were washed three times 
with PBS, then resuspended in RPMI medium without fetal bovine serum $\left(5 \times 10^{5}\right.$ cells $\left./ \mathrm{ml}\right)$ and incubated with FITClabeled concanavalin A (ConA), Sambucus nigra agglutinin (SNA) and wheat germ agglutinin (WGA), all three obtained from EY Laboratories Inc. (USA), at a concentration of 1 $\mathrm{mg} / \mathrm{l}$ in a humidified atmosphere supplemented with $5 \%$ $\mathrm{CO}_{2}$ at $37^{\circ} \mathrm{C}$ for $60 \mathrm{~min}$. After incubation, the cells were washed three times with PBS, and labeled cells were counted with an Accuri C6 flow cytometer (BD Bioscience, USA).

\section{Lectin-based microarray assay}

Cells $\left(1 \times 10^{6}\right.$ cells per $\left.\mathrm{ml}\right)$ after 48 hours of cultivation in the presence of TNM $(0.1 \mu \mathrm{mol} / \mathrm{l})$ were washed three times with PBS, and crude membrane fractions were prepared with a ProteomeExtract Subcellular Proteome Extraction Kit (Calbiochem, USA) according to the manufacturer's instructions. These samples were diluted in PBS (protein concentration $0.05 \mathrm{mg} / \mathrm{ml}$ ) and printed onto epoxysilane-coated slides (NEXTERION Slide E, Schott, Germany). All samples were printed into identical subarrays onto these slides using a noncontact piezoelectric printer (Nano-Plotter NP2.1, GeSiM, Grosserkmannsdorf, Germany) at $14^{\circ} \mathrm{C}$ and $60 \%$ humidity. After printing, slides were kept at $4^{\circ} \mathrm{C}$ for $2 \mathrm{~h}$. Unoccupied epoxy groups on slides were blocked with $1 \mathrm{M}$ ethanolamine in PBS supplemented with $0.05 \%$ Tween 20 (PBST) at $4^{\circ} \mathrm{C}$ for $1 \mathrm{~h}$, and the slide was then washed. After washing, printed proteins were allowed to interact with the biotinylated lectins ConA, SNA and WGA (Vector, Burlingame, USA) at room temperature for $1 \mathrm{~h}$. Biotinylated lectins at the concentration of $12.5 \mu \mathrm{g} / \mathrm{ml}$ in PBST were loaded into subarrays using a multiwell microarray mask. After washing, slides were allowed to interact with streptavidin (Sigma Aldrich, $5 \mu \mathrm{g} / \mathrm{ml}$ in PBS) conjugated with the fluorescent label CFTM647 (Biotium, Hayward, USA) at room temperature for $15 \mathrm{~min}$. Slides were thoroughly washed with PBST and distilled water, and the residual water was removed by centrifuging the slides. Dry slides were scanned by an InnoScan ${ }^{\circledR} 710$ fluorescence scanner (Innopsys, Carbonne, France). Fluorescent signals were analyzed by Mapix ${ }^{\circledR}$ 5.5.0 software (Innopsys). Specific fluorescent signals were calculated by subtracting background signal from the total measured signal and are expressed in arbitrary units.

\section{Results}

\section{Characterization of L1210, SKM-1 and MOLM-13 MDR variants}

Parental L1210, SKM-1 and MOLM-13 cells contain mRNA encoding multidrug resistance associated protein MRP1 (another ABC drug transporter, a product of the MRP1 gene) (Cole 2014, Fig. 2A). We were attempting to induce P-gp expression in SKM-1 and MOLM-13 cells by selection with VCR and LEN (Imrichova et al. 2015). While VCR was effective in inducing P-gp in both SKM-1 and MOLM-13 cells, LEN induced P-gp expression in SKM-1 cells only (Fig. 2A). Induction of P-gp expression either with VCR and LEN in SKM-1 cells or with VCR in MOLM-13 cells led to downregulation of $M R P 1$ expression. However, P-gp-overexpressing cell variant L1210/R, obtained by selection of with VCR (Polekova et al. 1992), expressed a similar amount of MRP1 transcript as parental L1210 cells (Fig. 2A). The expression of MRP1 was not changed in L1210/T cells (Fig. 2A). The expression of P-gp at the protein level and its efflux activity measured with the calcein retention assay has been reported for L1210/R and L1210/T cells (Sulova et al. 2010) and for SKM-1/VCR, SKM-1/LEN and MOLM-13/VCR cells (Imrichova et al. 2015). P-gp in cell variants L1210/R, L1210/T, SKM-1/VCR, SKM-1/LEN and MOLM-13/VCR caused MDR to the P-gp

Table 1. $\mathrm{IC}_{50}$ values for cisPt, DOX, MTX and VCR in drug sensitive and drug resistant variants of L1210, SKM-1 and MOLM-13 cells

\begin{tabular}{lcccc}
\hline & \multicolumn{3}{c}{ IC $_{50}$} \\
\cline { 2 - 5 } & $\begin{array}{c}\text { cisPt } \\
(\mu \mathrm{mol} / \mathrm{l})\end{array}$ & $\begin{array}{c}\text { DOX } \\
(\mathrm{nmol} / \mathrm{l})\end{array}$ & $\begin{array}{c}\text { MTX } \\
(\mathrm{nmol} / \mathrm{l})\end{array}$ & $\begin{array}{c}\text { VCR } \\
(\mathrm{nmol} / \mathrm{l})\end{array}$ \\
\hline L1210 & $3.40 \pm 0.50$ & $0.426 \pm 0.056$ & $\mathrm{nd}$ & $0.748 \pm 0.067$ \\
L1210/R & $7.03 \pm 0.53^{*}$ & $92.5 \pm 8.7^{*}$ & $\mathrm{nd}$ & $146 \pm 11.9^{*}$ \\
L1210/T & $7.20 \pm 0.47^{*}$ & $88.6 \pm 9.1^{*}$ & $\mathrm{nd}$ & $151 \pm 12.4^{*}$ \\
SKM-1 & $7.55 \pm 1.28$ & $0.113 \pm 0.014$ & $0.198 \pm 0.011$ & $0.251 \pm 0.018$ \\
SKM-1/LEN & $6.21 \pm 0.93$ & $135 \pm 13^{*}$ & $18.2 \pm 2.0^{*}$ & $50.3 \pm 2.1^{*}$ \\
SKM-1/VCR & $4.47 \pm 0.79^{+}$ & $189 \pm 12^{*}$ & $32.1 \pm 2.4^{*}$ & $108.6 \pm 5.2^{*}$ \\
MOLM-13 & $6.40 \pm 0.69$ & $0.132 \pm 0.009$ & $0.227 \pm 0.021$ & $0.178 \pm 0.021$ \\
MOLM-13/LEN & $6.23 \pm 0.47$ & $0.148 \pm 0.012$ & $0.192 \pm 0.017$ & $0.194 \pm 0.014$ \\
MOLM-13/VCR & $3.87 \pm 0.64^{+}$ & $168 \pm 17^{*}$ & $41.6 \pm 4.1^{*}$ & $98.9 \pm 7.3^{*}$ \\
\hline Datareprest
\end{tabular}

Data represent mean \pm S.E.M. for three independent measurements. Significance: ${ }^{*} p<0.01 v$ s. L1210, SKM-1 or MOLM- $13 ;{ }^{+} 0.05<p<0.1$ only marginal significance were found for differences between respective value and those obtained for L1210, SKM-1 or MOLM-13. cisPt, cisplatin; DOX, doxorubicin; MTX, mitoxantrone; VCR, vincristine; nd, not determined. 
substrates VCR, MTX and DOX, achieving a decrease in cell sensitivity of 80-1,000 times (Table 1). In contrast, P-gppositive human AML cells (SKM-1/VCR, SKM-1/LEN and MOLM-13/VRC) are slightly more sensitive to cisPt (Table 1), which is not a P-gp substrate (Gibalova et al. 2012). Interestingly, P-gp-positive L1210 cell variants L1210/R and L1210/T were two times less sensitive to latter anticancer drugs than P-gp-negative counterpart (Table 1).
Sensitivity of P-gp-negative and P-gp-positive cell variants to TNM

Sensitivity to TNM was monitored by flow cytometry using double staining of cells with FAV and PI. Typical dot-blot documentation of this measurement is shown in Fig. 2B. This procedure enabled us to distinguish: i. viable cells that were not stained by either label in lower-left quadrant; ii. early-
A
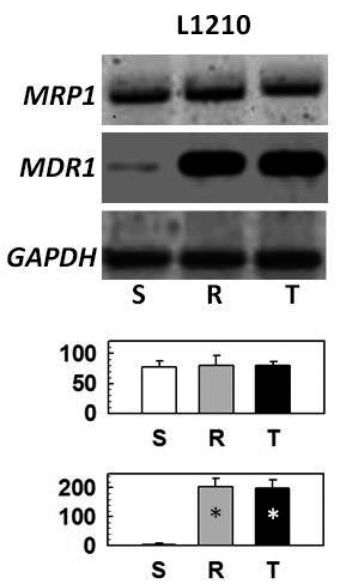

B

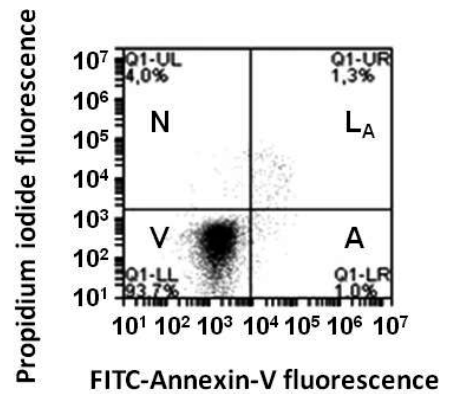

FITC-Annexin-V fluorescence

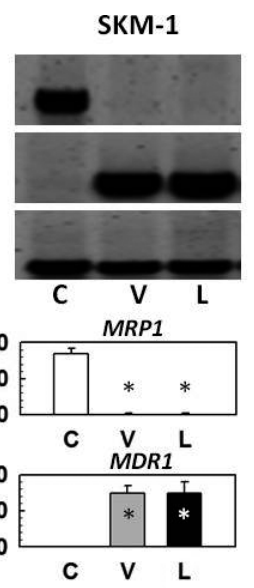

MOLM-13
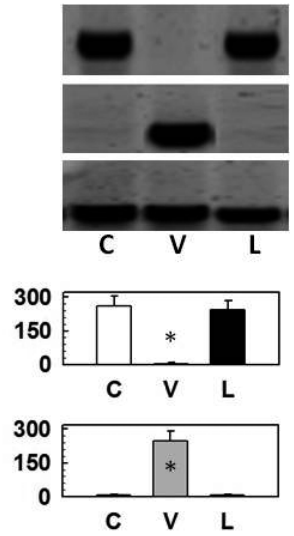
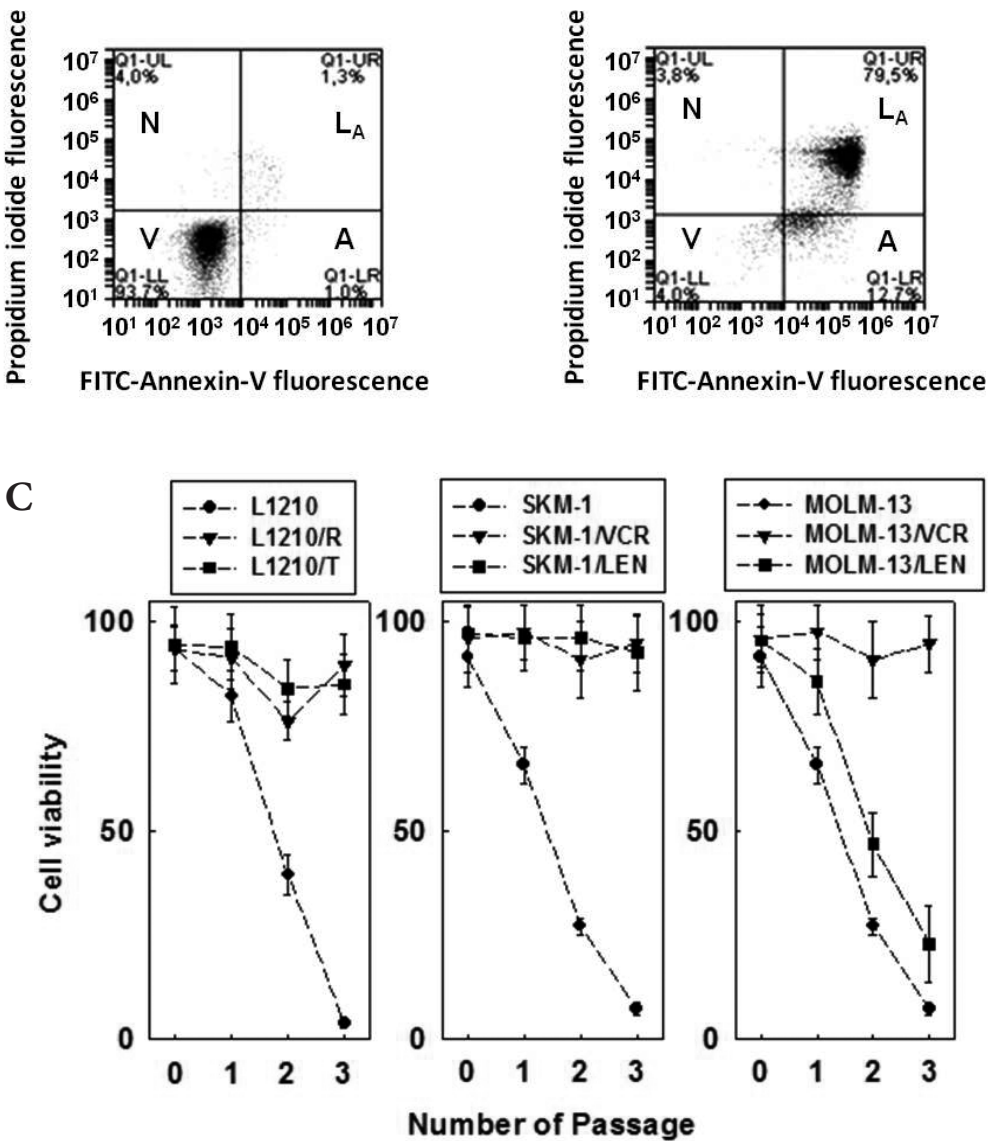

Figure 2. Resistance of P-gp-positive cells to TNM. A. Expression of MDR1 and MRP1 genes in leukemia cells. Upper part: Detection of transcripts by RT PCR. The data shown are representative of three independent measurements. Lower part: Quantification of PCR products. The data are expressed as the mean values \pm S.E.M. from three independent measurements; ${ }^{*}$ levels differ significantly from those of $\mathrm{S}$ or $\mathrm{C}(p<0.01)$. B. Typical record of apoptosis/necrosis detection by the FAV and PI apoptosis necrosis kit. Data shown were obtained for SKM-1 cells passaged twice in the absence (left part) or presence of TNM (right part). C. Cell viability, detected in the lower-left panels of the apoptosis/necrosis cytogram (see panel B) for P-gp-negative and P-gp-positive L1210, SKM-1 and MOLM-13 cells passaged 1, 2 or 3 times in the presence of TNM. The data are expressed as the mean values \pm S.E.M. from three independent measurements. Differences between P-gp-positive and Pgp-negative cells were always significant $(p<$ $0.01)$ after the second passage in the presence of TNM. S, L1210 cells; R, L1210/R; T, L1210/T cells; C, SKM-1 and MOLM-13 cells; V, SKM-1/VCR and MOLM-13/VCR cells; L, SKM-1/LEN and MOLM-13/LEN cells; FAV, fluorescein isothiocyanate-labeled annexin V; PI, propidium iodide; TNM, tunicamycin. 
apoptotic cells stained by FAV in the lower-right quadrant; iii. early-necrotic cells stained by PI in the upper-left quadrant; and iv. cells under late apoptosis or necrosis stained by both labels in the upper-right quadrant. The proportion of viable cells (in the lower-left quadrant) was detected in cells passaged one, two, and three times in the presence of TNM, and this was compared with cells passaged in the absence of this inhibitor. TNM depressed cell viability of P-gp-negative L1210, SKM-1, MOLM-13 and MOLM-13/LEN cells. After the third passage, the proportion of viable cells was less than $10 \%$ (Fig. 2C). In contrast, no cell viability reduction of P-gppositive L1210/R, L1210/T, SKM-1/VCR, SKM-1/LEN and MOLM-13/VCR cells was observed after the third passage with TNM. Therefore, all P-gp-positive leukemia cells used in this study could be considered cross-resistant to TNM.

P-gp negative cells in this study grew in the absence of TNM as single, unclustered cells, which is typical for leukemia cells (Fig. 3A). In contrast, L1210/R cells showed a tendency to grow in multi-cell clusters. Passaging of Pgp-negative cells (L1210, SKM-1, MOLM-13 and MOLM13/LEN) with TNM reduced the cell numbers, and after the third passage only a few cells could be observed by light microscopy (Fig. 3A). In contrast, passaging of P-gp- positive cells (L1210/R, L1210/T, SKM-1/VCR, SKM-1/ LEN and MOLM-13/VCR) in medium with TNM did not reduce the cell number, but the cells showed a strong tendency to form multi-cell clusters (Fig. 3A). For cell counting, these clusters were disrupted by stirring the cells in suspension.

After cultivation of L1210 cells in the presence of TNM, cellular ultrastructures were altered (Fig. 3B). A strong tendency for the formation of intracellular vacuoles was visible. In contrast, no similar changes to cell ultrastructure were present in P-gp-positive L1210/R cells under passaging in the presence of TNM. The TNM-induced alterations to L1210 and L1210/R cell architecture documented in Fig. $3 \mathrm{~B}$ are representative of all pairs of P-gp-negative and P-gppositive cells used in this study.

P-gp-negative (L1210, SKM-1, MOLM-13 and MOLM13/LEN) after the first passage with TNM were mostly viable (Fig. 4), but a significant increase in the proportion of cells in early apoptosis (SKM-1, MOLM-13 and MOLM-13/ LEN, Fig. 4B and C) or early necrosis (L1210, Fig. 4A) was observed in comparison with cells cultivated in absence of TNM. The proportions of viable cells were decreased after the second passage with TNM to values lower that 50\%.

A
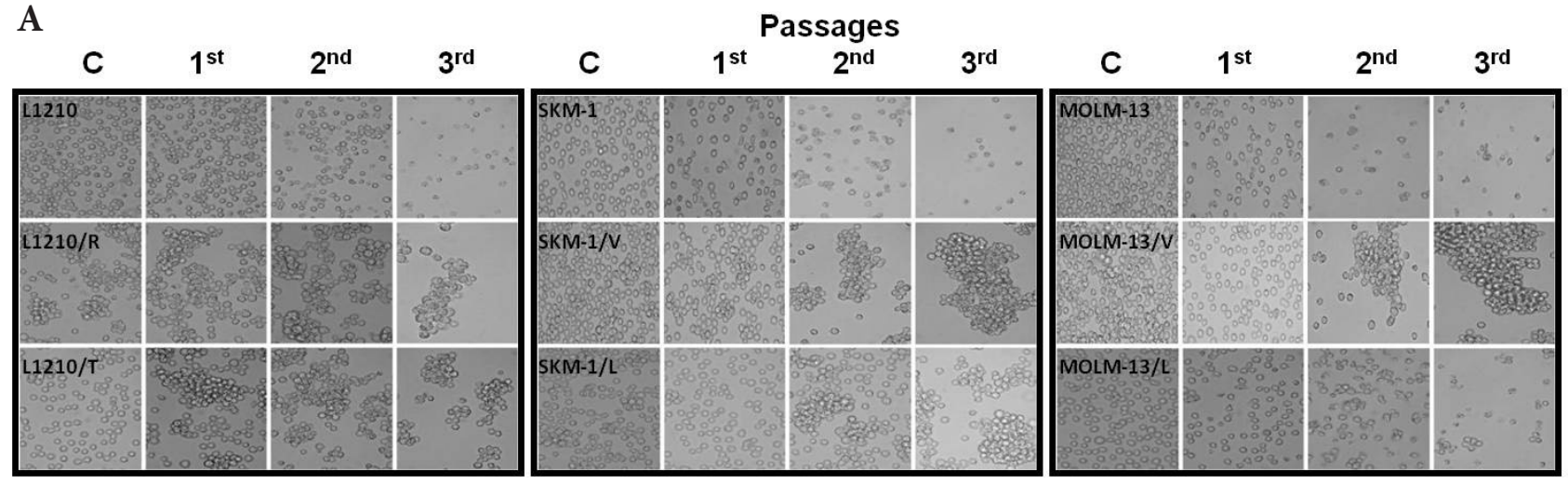

B

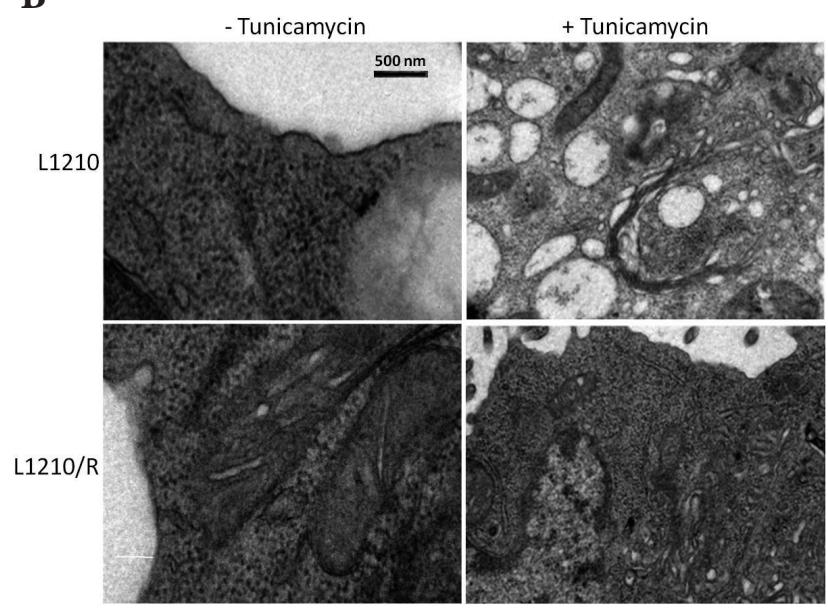

Figure 3. Structural characteristics of P-gp-positive and P-gpnegative leukemia cells. A. Light microscopy (magnification $\times 100$ ). Cells were passaged one $\left(1^{\mathrm{st}}\right)$, two $\left(2^{\text {nd }}\right)$ or three $\left(3^{\text {rd }}\right)$ times in the presence of tunicamycin and compared with control untreated cells (C). SKM-1/V and SKM-1/L represent SKM-1/VCR and SKM-1/ LEN cells; MOLM-13/V and MOLM-13/L represent MOLM-13/ VCR and MOLM-13/LEN cells. The data shown are representative of three independent measurements. B. Electron microgram of L1210 and L1210/R cells passaged in the absence or presence of tunicamycin. 
After the third passage, the large majority of P-gp-negative cells were in late apoptosis/necrosis, i.e., the upper-right quadrant in flow cytometry. In contrast, passaging in the presence of TNM did not induce such massive cell death

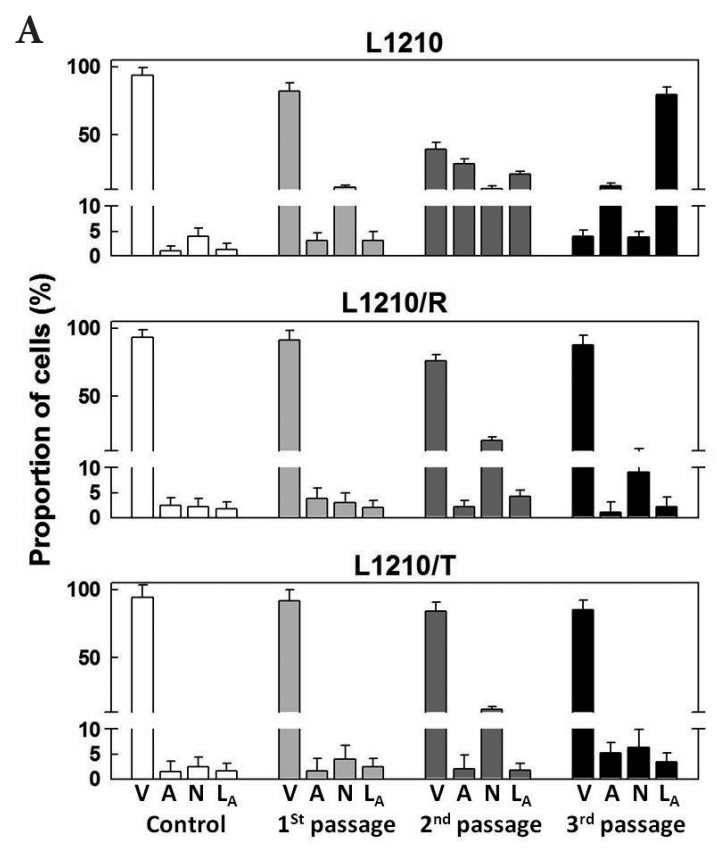

B
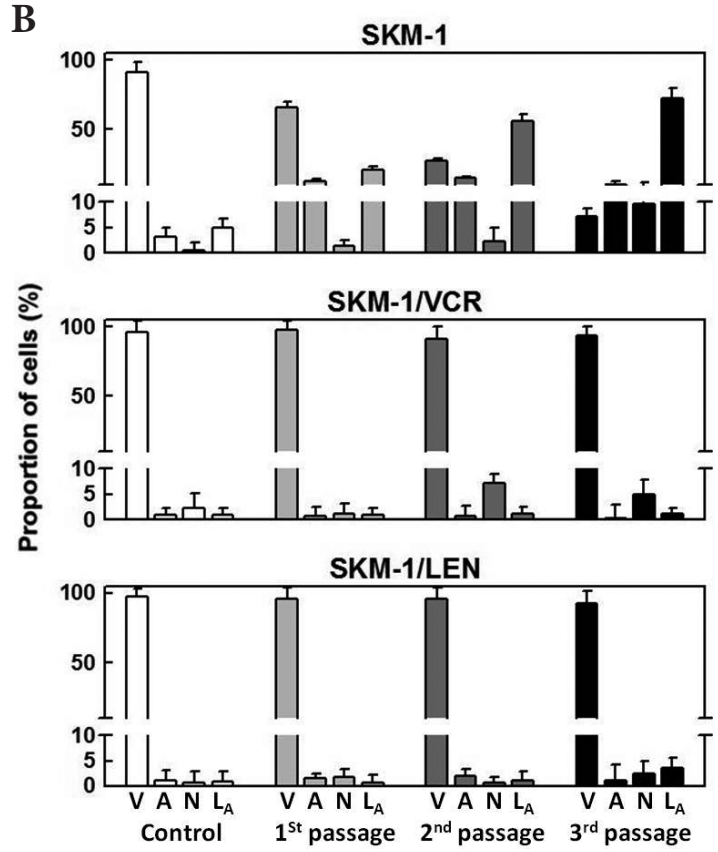

progression in any variant of P-gp-positive cells (L1210/R, L1210/T, SKM-1/VCR, SKM-1/LEN and MOLM-13/VCR, Fig. 4).

Effect of cell cultivation in the presence of TNM on cell cycling

We observed cell cycling using flow cytometry by counting cells with DNA stained with PI (Fig. 5A). This method enabled us to distinguish between cells in the G1 phase (with normal content of DNA), the S phase (with increased content of DNA due to replication), the G2/M phase (with double the amount of DNA) and the sub-G1 phase (apoptotic cells, with less DNA than in the G1 phase due to DNA fragmentation). Cultivation of P-gp-negative (L1210, SKM-1, MOLM-13 and MOLM-13/LEN) cells in medium containing TNM for 24 hours increased the proportion in the subG1 phase (Fig. 5B). Cultivation of cells for an additional 24 hours augmented this effect in L1210 cells, while in other $\mathrm{P}$-gp-negative cells the proportions remained similar to after 24 hours. In contrast, only minor (if any) increases of P-gppositive cells (L1210/R, L1210/T and SKM-1/LEN Fig. 5B) in the subG1 phase were registered after their cultivation in medium containing TNM for 24 and 48 hours (Fig. 5B).

Cells in the subG1 phase were omitted and only viable cells were accounted to document the cells in the different

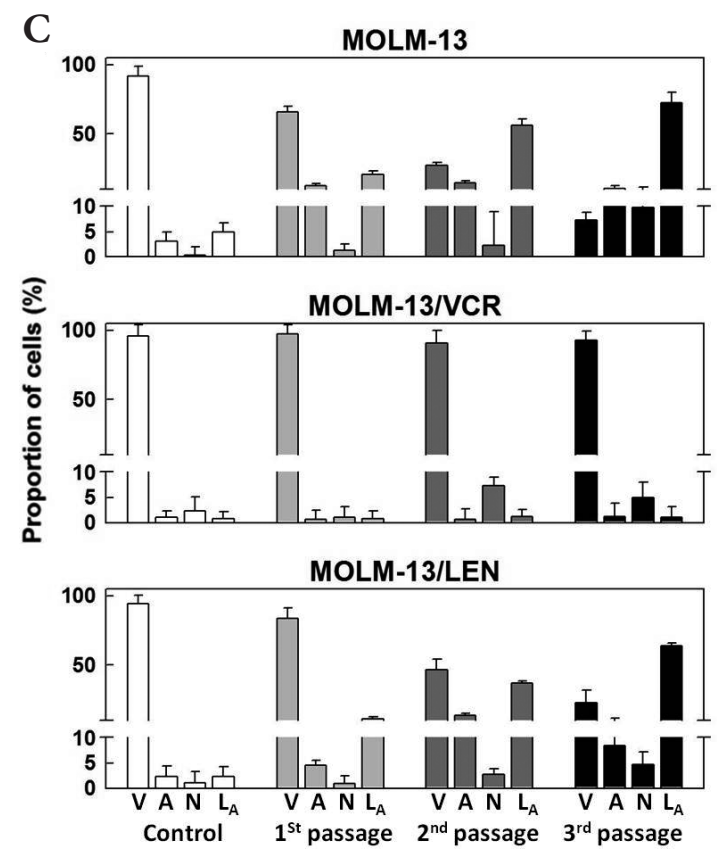

Figure 4. Detection of apoptosis and necrosis by the FAV and PI apoptosis-necrosis kit. V, viable cells in the lower-left quadrant; A, early-apoptotic cells in the lower-right quadrant; $\mathrm{N}$, early-necrotic cells in the upper-left quadrant; $\mathrm{L}_{\mathrm{A}}$, late-apoptotic/necrotic cells in the upper-right quadrant. For documentation of methods, see Fig 2B. The data are expressed as the mean values \pm S.E.M. from three independent measurements. 
phases of the cell cycle. After cell cultivation of P-gp-negative cells for 24 or 48 hours in medium containing TNM, the proportion of each cell type in the G1 phase was increased and in the $\mathrm{S}$ and G2/M phases was decreased (Fig. 5C and D). Thus, TNM induced cell cycle arrest in the G1 phase in P-gp-negative cells. In contrast, cultivation of P-gp-positive cells in medium containing TNM did not induce such pronounced changes in cell cycling (Fig. 5C and D).

Interaction of $P$-gp-negative and $P$-gp-positive cell surfaces with ConA, SNA and WGA

The ability of ConA, SNA and WGA to attach to the surface of membranes was measured with two methods: i. by cytometry of whole cells labeled with FITC-lectins and ii. by lectin-based microarray assay using crude membrane fractions. Binding of FITC-ConA to whole-cell surfaces was not very intensive; Fig. 6 documents the results from the lectin-based microarray. Measurement of SNA interactions gave similar results independently of those two methods and Fig. 6 documents the results from the lectin-based microarray. However, this method gave only small signals for WGA, and these data are replaced by the results of flow cytometry with whole cells, which gave more intensive signals. ConA labeled P-gp-negative cells (L1210, SKM-1, MOLM-13 and MOLM-13/LEN) more intensively than Pgp-positive cells (L1210/R, L1210/T, SKM-1/VCR, SKM-1/ LEN and MOLM-13/VCR, Fig. 6). Cultivation of L1210, L1210/R and L1210/T cells in medium containing TNM decreased ConA binding to cell surfaces of all three cell variants. However, while TNM decreased ConA biding to P-gpnegative SKM-1, MOLM-13 and MOLM-13/LEN cells, their P-gp-positive counterparts (SKM-1/VCR, SKM-1/LEN and MOLM-13/VCR) interacted with ConA more potently after treatment with TNM (Fig. 6). Interaction of P-gp-negative L1210 cells with SNA was slightly more pronounced than in P-gp-positive L1210/R and L1210/T cells. Similarly to ConA, binding of SNA after treatment of L1210 cell variants with TNM showed tendency to be decreased (Fig. 6). In contrast to L1210 cells, P-gp-positive variants of human AML cells (SKM-1/VCR, SKM-1/LEN and MOLM-13/VCR) interacted with SNA more potently than P-gp-negative cells (SKM-1, MOLM-13 and MOLM-13/LEN). Cultivation of cells in medium containing TNM induced: i. a decrease of SNA binding to SKM-1; ii. an increase of SNA binding to SKM-1/VCR cells and iii. unchanged SNA-binding levels for SKM-1/LEN, MOLM-13, MOLM-13/VCR and MOLM-13/ LEN cells. Binding of WGA to P-gp-positive cells (L1210/R, L1210/T, SKM-1/VCR, SKM-1/LEN and MOLM-13/VCR) were more intensive than on P-gp-negative cells (SKM-1, MOLM-13 and MOLM-13/LEN). Cultivation of all variants of cells in TNM induced a tendency of cells to bind lower amounts of WGA than untreated cells (Fig. 6).

\section{Discussion}

The most important finding of the current paper is that P-gp-positive leukemia cell variants were resistant to TNM-induced cell death effects (Fig. 2C). TNM is generally accepted to decrease protein $\mathrm{N}$-glycosylation in the endoplasmic reticulum. This activity also affects $\mathrm{P}$-gp posttranslational processing and is responsible for the presence of the unglycosylated P-gp variant $(140 \mathrm{kDa})$ when HEK 293 cells transfected with wild-type and P709A mutant P-gp are treated with TNM (Loo and Clarke 1993). We have observed similar unglycosylated P-gp variants in L1210/R and L1210/T cells treated with TNM and thapsigargin in previous papers (Seres et al. 2010, 2011). Unglycosylated P-gp variants localize to the plasma membrane and show calcein efflux activity in these cell variants treated with TNM (Seres et al. 2011).

The exact mechanism of TNM resistance in P-gp-positive leukemia cells is not fully understood. The most simple explanation of this resistance represents the possibility that TNM may be a substrate for P-gp efflux and that this antibiotic is therefore eliminated from the intracellular space of cells and cannot induce the cell death effects (Hiss et al. 1996). However, direct evidence for such P-gp activity is missing. The fact that TNM is able to block protein glycosylation, including P-gp itself, in P-gp-positive cells (Morin and Bernacki 1983; Loo and Clarke 1993; Seres et al. 2011) is contradictory to this speculation. Moreover, resistance of L1210/R and L1210/T cells to TNM could not be reversed by verapamil (a known P-gp inhibitor) even if this substance completely blocked P-gp efflux activity measured by calcein retention assay (Orlicky et al. 2004; Sulova et al. 2005). TNM enhances the sensitivity of not only drug-resistant NIH-3T3-MDR cells but also drugsensitive NIH-3T3 cells to P-gp substrates (such as DOX and VCR) or to cisPt, a P-gp-untransportable drug (Hiss et al. 1996). These pharmacomodulatory effects of TNM are assumed to be mediated by global inhibition of protein and glycoprotein synthesis and synergistic interaction with antineoplastic drugs (Hiss et al. 2007). Hiss et al. (2007) also concluded that the ability of TNM to enhance the sensitivity of drug-resistant tumor cells may impact the design and optimization of novel resistance modifiers for combination treatment of intractable neoplasms. Application of TNM increases the cellular level of UDP-N-acetylglucosamine, which was associated with distention of the endoplasmic reticulum and the nuclear membranes (Morin and Bernacki 1983). Similar ultrastructural changes and increases in the intracellular pool of UDP-sugars were observed in L1210 cells exposed to $5 \mathrm{mmol} / \mathrm{l} \mathrm{D}$-glucosamine, which suggests that the antiproliferative effects of TNM may be related to the accumulation of one or more of the nucleotidesugar precursors of asparagine-linked glycoprotein biosynthesis in the endoplasmic reticulum (Morin and Bernacki 1983). Significantly decreased intracellular levels of UDP-sugars have been detected using ${ }^{31} \mathrm{P}-\mathrm{NMR}$ when P-gp-positive L1210/R 
cells were compared with P-gp-negative counterparts (Fiala et al. 2003). Decreased UDP-glucose is observed in L1210/R and L1210/T cells compared with parental L1210 cells (Turakova et al. 2015). Therefore, the resistance of P-gp-positive L1210 cells to TNM may be caused by the decreased levels of UDP-sugars in these cells. This may finally depress the ability of TNM to induce accumulation of UDP-sugar precursors for protein $\mathrm{N}$-glycosylation in endoplasmic reticulum. In mammalian cells a correlation between the TNM resistance and UDP-Nacetylglucosamine:dolichol phosphate $\mathrm{N}$-acetylglucosamine- 1-phosphate transferase activity has been observed (Zhu et al. 1992). To determine if the expression and activity of this enzyme is altered under the development of P-gp-mediated MDR, future research will be necessary. However, fact that TNM resistance is observed in all P-gp-positive leukemia cell variants used in the current paper indicates that presence of P-gp could be crucial for reduced cellular response to this antibiotic, even if this feature is independent of P-gp efflux activity. This resistance cannot be explained as a response of cells to the presence of VCR or LEN during the establishment
A

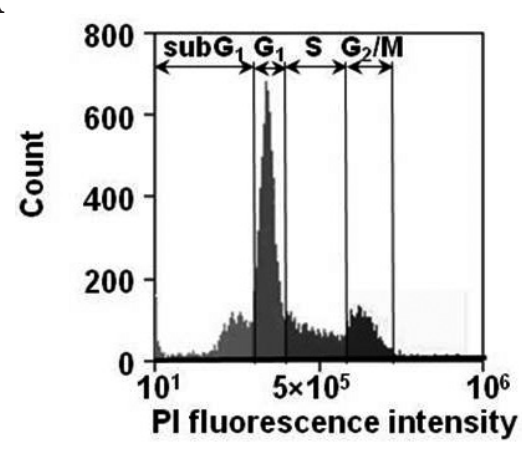

B

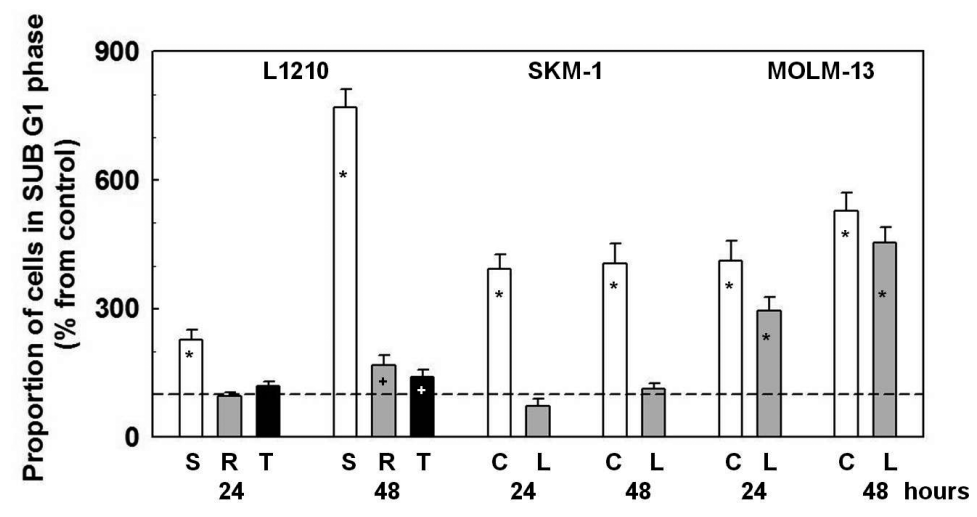

$\mathrm{D}$
$\mathrm{C}$

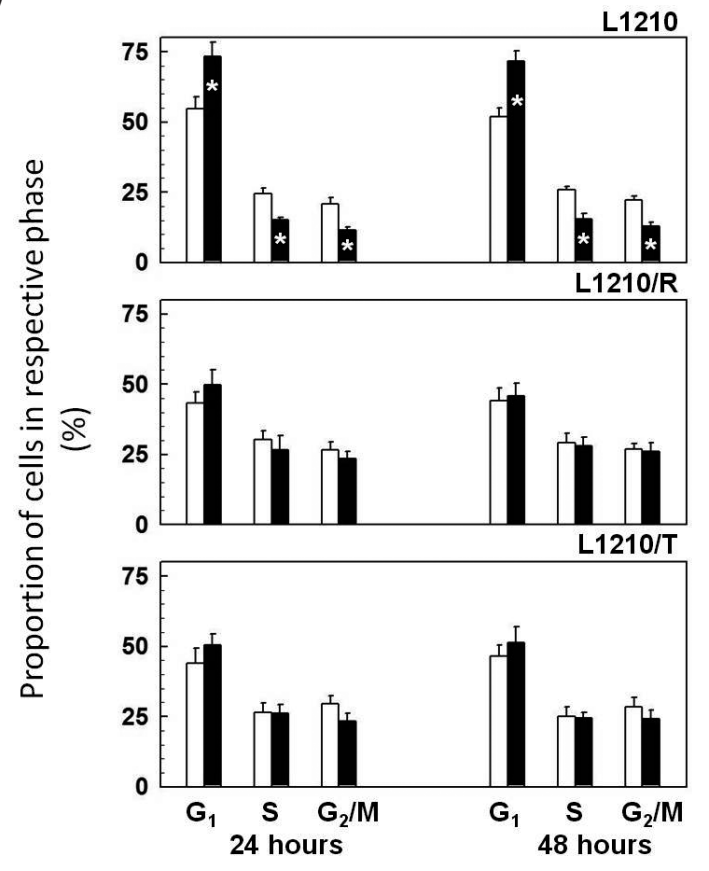

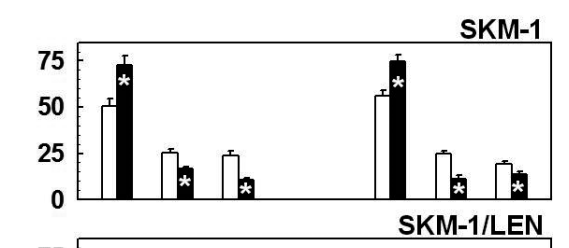
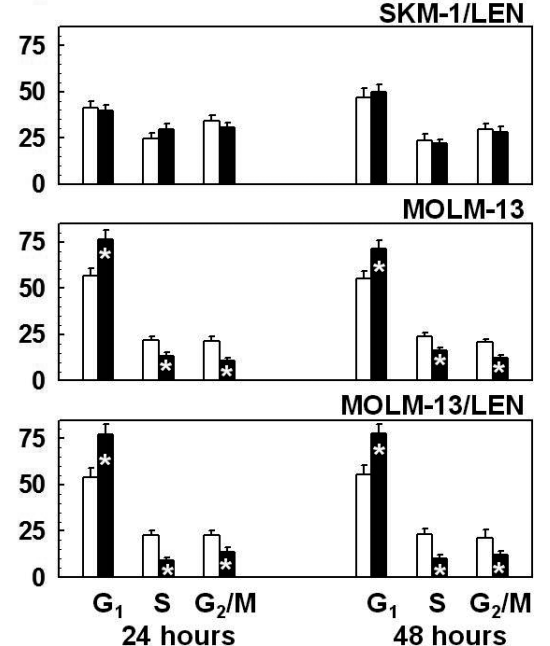

Figure 5. Proportions of cells in the different phases of the cell cycle after their cultivation in the presence or absence of TNM. A. Phase of cell cycle detected by staining of DNA with PI (L1210 cells). B. Quantification of cells in the subG1 phase (apoptotic cells) after 24- or 48-hour cultivation in the presence of TNM. S, L1210 cells; R, L1210/R; T, L1210/T cells; C, SKM-1 and MOLM-13 cells; L, SKM-1/LEN and MOLM$13 / \mathrm{LEN}$ cells. Data are expressed as the mean \pm S.E.M. from three independent measurements and are expressed in percentage of control experiment in the absence of TNM. ${ }^{\star} p<0.01,{ }^{+} p<0.05 v$ s. control. C and D. Quantification of P-gp-positive and P-gp-negative cells in the different phases of the cell cycle after cultivation of cells in the presence (black column) or absence (white column) of TNM for 24 or 48 hours. The data are expressed as the mean values \pm S.E.M. from three independent measurements. ${ }^{\star} p<0.01 v s$. control in the absence of TNM. 
of MDR variants because the resistance is fully developed in L1210/T cells that express P-gp due to transfection with the human P-gp gene.

P-glycoprotein-overexpressing L1210/R and L1210/T cell variants were less sensitive to cisPt than parental L1210 $\mathrm{S}$ cells (Table 1). Similar decrease of cell sensitivities were not observed in P-gp positive human AML cells when compared with P-gp negative counterparts. P-gp-induced partial loss of L1210 cell sensitivity to cisPt was associated with deregulation of mitochondrial apoptotic pathway. This was connected with depression in caspase-3 activation in Pgp-positive R and T cells (Gibalova et al. 2012). Differences in apoptotic progression in P-gp positive L1210 cells may be partially involved in resistance of these cells also to TNM.

TNM induced combined apoptosis/necrosis cell death in P-gp-negative L1210 cells. In contrast, apoptosis was the prevalent mode of cell death induced by TNM in P-gp-negative human AML cells (SKM-1, MOLM-13 and MOLM-13/ LEN, Fig. 4). Arrest of cells in the G1 phase could be considered a typical feature linked with TNM-induced cell damage in all P-gp-negative cell variants applied in this study (Fig. 5). Similarly, arrest in the G1 phase has been described in hepatocellular carcinoma cells and NIH 3T3 after treatment with TNM (Madhavan et al. 2000; Hsu et al. 2009).
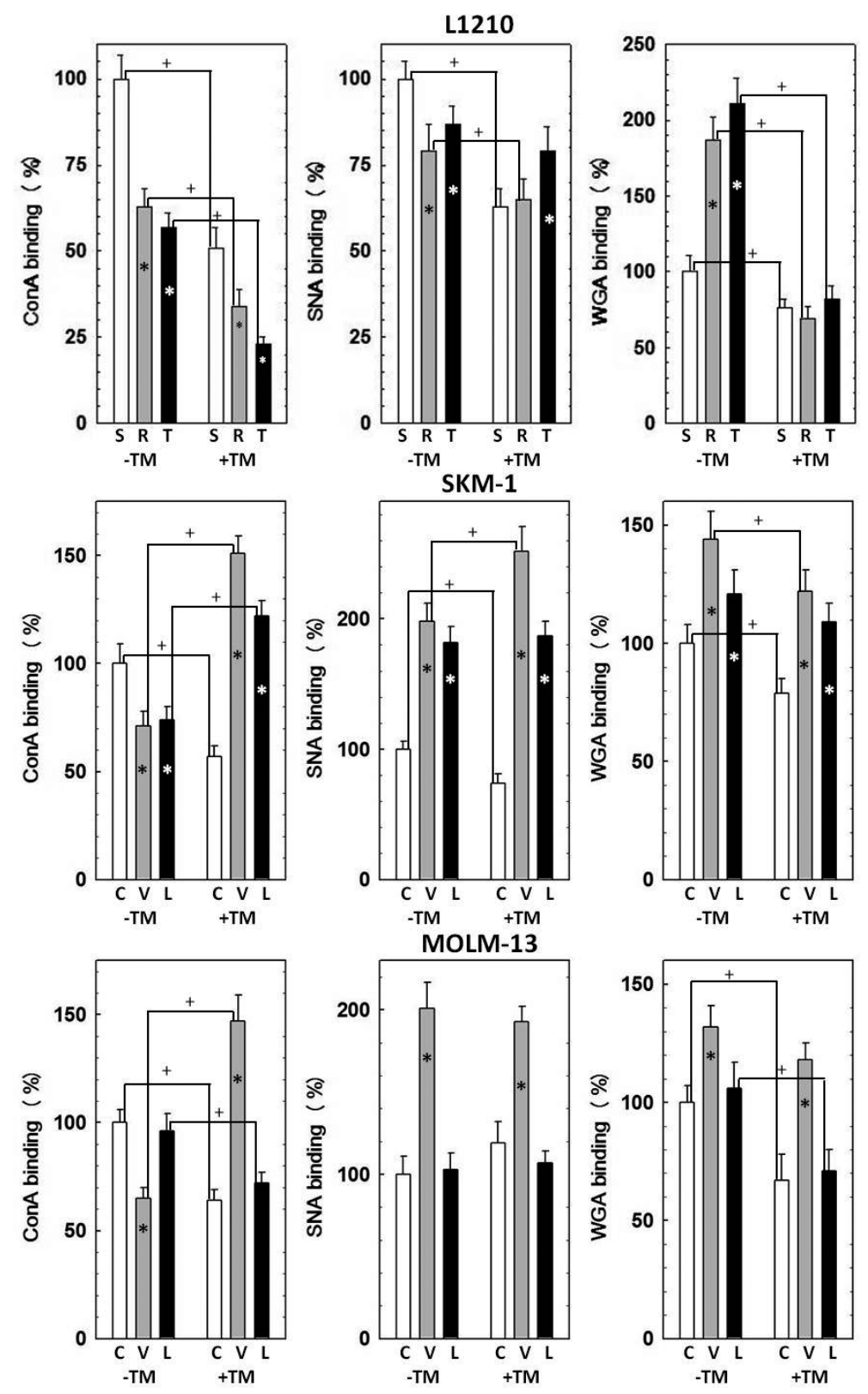

Figure 6. Concanavalin A (ConA) and Sambucus nigra agglutinin (SNA) binding to crude membrane fractions (detected by lectin-based microarray assay) and wheat germ agglutinin (WGA) binding to the cell surface (detected by flow cytometry) of Pgp-negative and P-gp-positive leukemia cells. The data are expressed as the mean values \pm S.E.M. from three independent measurements. ${ }^{\star} p<0.02$ vs. control $\mathrm{C},{ }^{+} p<0.02$ $v s$. control in the absence of TNM. S, L1210 cells; R, L1210/R; T, L1210/T cells; C, SKM1 and MOLM-13 cells; V, SKM-1/VCR and MOLM-13/VCR cells; L, SKM-1/LEN and MOLM-13/LEN cells. 
In P-gp-positive L1210/R cells, a tendency to form multicellular clusters during cultivation was clearly visible (Fig. 3A). A similar feature has been described previously (Uhrik et al. 2006). This tendency was less pronounced but still existed in SKM-1/VCR, SKM-1/LEN and MOLM-13/VCR cell variants (Fig. 3A). TNM treatment induced an additional increase of cell clustering of P-gp-positive cells during passaging (Fig 3A). This behavior was caused by alteration of cell surface physico-chemical properties that enabled tight contacts between cells. Saccharides attached to proteins or lipids of lipoprotein complexes of the plasma membrane are an important part of the cell surface composition, and alterations of their composition could be responsible for changes in cell:cell interactions and overall cell clustering. Therefore, we studied whether the composition of cell surface sugars was different between P-gp-positive and P-gp-negative leukemia cells using the lectins ConA, SNA, and WGA.

Oligo- and/or polysaccharide contents in P-gp-positive L1210/R were decreased compared with P-gp-negative L1210 cells (Fiala et al. 2003). This indicated that induction of P-gp in neoplastic cells is associated with alterations in transglycosylation reactions, including glycosylation of proteins (reviewed in Breier et al. 2005). Such alterations of protein glycosylation are responsible for changes in glycoprotein contents that can be detected by lectins in isolated fractions of intracellular proteins (Fiala et al. 2003) or in surface proteins detected on whole cells (Sulova et al. 2009, 2010; Bubencikova et al. 2012). Changes in cell surface glycoproteins are considered responsible for the ConA resistance of non-differentiating L6 myoblasts selected for resistance to this lectin (Parfett et al. 1983). Both P-gppositive variants of L1210 cells (L1210/R and L1210/T) are less sensitive to ConA than the parental L1210 cells (Fiala et al. 2003; Sulova et al. 2009, 2010). This resistance is based on a lower binding capacity of the cell surface of resistant cells to ConA than sensitive cells. Alterations of the cell surface binding capacity of the tomato lectin (Lycopersicum esculentum agglutinin, Sulova et al. 2009), SNA and WGA (Bubencikova et al. 2012) on the cell surface of P-gp-positive L1210 cells are associated with altered cell death effects induced by these lectins. These facts indicate that expression of P-gp in L1210 cells alters the cell surface sugar composition, and the composition of cell surface sugars is associated with changes to the binding and cell death effect of lectins. Similarly to the P-gp-positive variant of L1210 cells, the P-gp-positive variants of human AML cells (SKM-1/VCR, SKM-1/LEN and MOLM-13/VCR) bound lower levels of ConA on their surfaces than their Pgp-negative counterparts (Fig. 6). We showed previously that ConA does not interact with sugars attached directly to P-gp and labels other proteins in the crude plasma membrane fraction, using lectin eastern blots (Sulova et al. 2009, 2010). In contrast to ConA, Galanthus nivalis agglutinin (Seres et al. 2011) and SNA (Bubencikova et al. 2012) bind to sugar moieties linked directly to P-gp. While treatment with TNM decreased the binding of ConA to all variants of L1210 cells, in human AML cells a decrease in ConA binding after TNM treatment was observed only in P-gp-negative cell variants (SKM-1, MOLM-13 and MOLM-13/LEN). P-gp-positive cell variants (SKM-1/VCR, SKM-1/LEN and MOLM-13/VCR) interacted after TNM treatment with ConA most intensively. In contrast to ConA, WGA interacted more intensively with P-gp-positive cells than with P-gp-negative cells. Improvement of WGA binding to P-gp-positive cells could be associated with the direct interaction of lectin with glycosides attached to P-gp. This interaction could be related to the fact that P-gp can be isolated by WGA-lectin chromatography with Nacetylglucosamine elution (Ambudkar et al. 1998). However, we have failed to observe a direct interaction between WGA and P-gp on lectin blots in a previous paper (Bubencikova et al. 2012). The reason for these contradictory findings has to be resolved in the future. Glycosides attached to P-gp are an important proportion of available saccharide ligands for this lectin due to massive overexpression of $\mathrm{P}$-gp in resistant variants of L1210, SKM-1 and MOLM-13 cells (Sulova et al. 2010; Imrichova et al. 2015; Messingerova et al. 2015a).

Study of the interactions of the three lectins with the cell surfaces of P-gp-positive and P-gp-negative variants of leukemia cells revealed remodeling of cell surface saccharides associated with the development of P-gp-mediated MDR. This remodeling seems to be a part of the extensive alterations of cells' homeostasis and architecture that occur as a secondary response to P-gp overexpression in MDR cells (reviewed in Breier et al. 2013). The origin of these alterations reflects differences in the profile of plasma membrane glycoproteins and indicates changes in the mechanisms that secure specific control of these proteins' expression.

\section{Conclusions}

Reduced sensitivity to TNM could occur in P-gp-positive leukemia cells. This cross-resistance may be attributed to altered regulation of protein-glycosylation pathways, particularly in the endoplasmic reticulum. A direct relation between the TNM resistance of P-gp-positive leukemia cells and P-gp efflux activity seems improbable. Overexpression of P-gp in leukemia cell is associated with alterations of cell surface sugars, which may differ by cell type.

Acknowledgments. This study was supported by grants from the Slovak APVV grant agency (No. APVV-14-0334, APVV-14-0753, APVV-15-0303) and the VEGA grant agency (Vega 2/0182/13, $2 / 0028 / 15,2 / 0156 / 16$ ) and by a Building Infrastructure for Modern Research of Civilization's Diseases project (ITMS 26230120006). The paper was edited for proper English language, grammar, punctuation, spelling, and overall style by one or more of the highly qualified native English-speaking editors at American Journal Experts. 


\section{References}

Ambudkar S. V., Lelong I. H., Zhang J., Cardarelli C. (1998): Purification and reconstitution of human P-glycoprotein. Methods Enzymol. 292, 492-504 http://dx.doi.org/10.1016/S0076-6879(98)92038-9

Andersen T. B., Lopez C. Q., Manczak T., Martinez K., Simonsen H. T. (2015a): Thapsigargin--from Thapsia L. to mipsagargin. Molecules 20, 6113-6127 http://dx.doi.org/10.3390/molecules20046113

Andersen V., Svenningsen K., Knudsen L. A., Hansen A. K., Holmskov U., Stensballe A., Vogel U. (2015b): Novel understanding of $\mathrm{ABC}$ transporters $\mathrm{ABCB} 1 / \mathrm{MDR} / \mathrm{P}$-glycoprotein, ABCC2/ MRP2, and ABCG2/BCRP in colorectal pathophysiology. World J. Gastroenterol. 21, 11862-11876 http://dx.doi.org/10.3748/wjg.v21.i41.11862

Breier A., Barancik M., Sulova Z., Uhrik B. (2005): P-glycoprotein-implications of metabolism of neoplastic cells and cancer therapy. Curr. Cancer Drug Targets 5, 457-468 http://dx.doi.org/10.2174/1568009054863636

Breier A., Gibalova L., Seres M., Barancik M., Sulova Z. (2013): New insight into p-glycoprotein as a drug target. Anticancer Agents Med. Chem. 13, 159-170 http://dx.doi.org/10.2174/187152013804487380

Bubencikova T., Cholujova D., Messingerova L., Mislovicova D., Seres M., Breier A., Sulova Z. (2012): Detection of glycomic alterations induced by overexpression of p-glycoprotein on the surfaces of L1210 cells using sialic acid binding lectins. Int. J. Mol. Sci. 13, 15177-15192 http://dx.doi.org/10.3390/ijms131115177

Colabufo N. A., Berardi F., Perrone M. G., Capparelli E., Cantore M., Inglese C., Perrone R. (2010): Substrates, inhibitors and activators of P-glycoprotein: candidates for radiolabeling and imaging perspectives. Curr. Top. Med. Chem. 10, 1703-1714 http://dx.doi.org/10.2174/156802610792928022

Cole S. P. (2014): Targeting multidrug resistance protein 1 (MRP1, ABCC1): past, present, and future. Annu. Rev. Pharmacol. Toxicol. 54, 95-117 http://dx.doi.org/10.1146/annurev-pharmtox-011613-135959

Fiala R., Sulova Z., El-Saggan A. H., Uhrik B., Liptaj T., Dovinova I., Hanusovska E., Drobna Z., Barancik M., Breier A. (2003): P-glycoprotein-mediated multidrug resistance phenotype of L1210/VCR cells is associated with decreases of oligo- and/or polysaccharide contents. Biochim. Biophys. Acta 1639, 213-224 http://dx.doi.org/10.1016/j.bbadis.2003.09.009

Gerlier D., Thomasset N. (1986): Use of MTT colorimetric assay to measure cell activation. J. Immunol. Methods 94, 57-63 http://dx.doi.org/10.1016/0022-1759(86)90215-2

Gibalova L., Sedlak J., Labudova M., Barancik M., Rehakova A., Breier A., Sulova Z. (2009): Multidrug resistant P-glycoprotein positive L1210/VCR cells are also cross-resistant to cisplatin via a mechanism distinct from P-glycoprotein-mediated drug efflux activity. Gen. Physiol. Biophys. 28, 391-403 http://dx.doi.org/10.4149/pb_2009_04_391

Gibalova L., Seres M., Rusnak A., Ditte P., Labudova M., Uhrik B., Pastorek J., Sedlak J., Breier A., Sulova Z. (2012): P-glycoprotein depresses cisplatin sensitivity in L1210 cells by inhibiting cisplatin-induced caspase-3 activation. Toxicol. in Vitro 26, 435-444 http://dx.doi.org/10.1016/j.tiv.2012.01.014

Heifetz A., Keenan R. W., Elbein A. D. (1979): Mechanism of action of tunicamycin on the UDP-GlcNAc:dolichyl-phosphate Glc-NAc-1-phosphate transferase. Biochemistry 18, 2186-2192 http://dx.doi.org/10.1021/bi00578a008

Hiss D., Gabriels G., Jacobs P., Folb P. (1996): Tunicamycin potentiates drug cytotoxicity and vincristine retention in multidrug resistant cell lines. Eur. J. Cancer 32A, 2164-2172 http://dx.doi.org/10.1016/S0959-8049(96)00262-6

Hiss D. C., Gabriels G. A., Folb P. I. (2007): Combination of tunicamycin with anticancer drugs synergistically enhances their toxicity in multidrug-resistant human ovarian cystadenocarcinoma cells. Cancer Cell Int. 7, 5 http://dx.doi.org/10.1186/1475-2867-7-5

Hsu J. L., Chiang P. C., Guh J. H. (2009): Tunicamycin induces resistance to camptothecin and etoposide in human hepatocellular carcinoma cells: role of cell-cycle arrest and GRP78. Naunyn Schmiedebergs Arch. Pharmacol. 380, 373-382 http://dx.doi.org/10.1007/s00210-009-0453-5

Imrichova D., Coculova M., Messingerova L., Sulova Z., Breier A. (2014): Vincristine-induced expression of P-glycoprotein in MOLM-13 and SKM-1 acute myeloid leukemia cell lines is associated with coexpression of nestin transcript. Gen. Physiol. Biophys. 33, 425-431 http://dx.doi.org/10.4149/gpb_2014015

Imrichova D., Messingerova L., Seres M., Kavcova H., Pavlikova L., Coculova M., Breier A., Sulova Z. (2015): Selection of resistant acute myeloid leukemia SKM-1 and MOLM-13 cells by vincristine-, mitoxantrone- and lenalidomide-induced upregulation of P-glycoprotein activity and downregulation of CD33 cell surface exposure. Eur. J. Pharm. Sci. 77, 29-39

http://dx.doi.org/10.1016/j.ejps.2015.05.022

Jipu R., Amititeloaie C., Zonda G. I., Iancu R. I., Carasevici E., Costuleanu M. (2012): Thapsigargin-induced endoplasmic reticulum stress is not accompanied by mitochondrial membrane potential dissipation in murine pro-B cells. Rev. Med. Chir. Soc. Med. Nat. Iasi 116, 557-562

Kupsakova I., Rybar A., Docolomansky P., Drobna Z., Stein U., Walther W., Barancik M., Breier A. (2004): Reversal of Pglycoprotein mediated vincristine resistance of L1210/VCR cells by analogues of pentoxifylline. A QSAR study. Eur. J. Pharm. Sci. 21, 283-293 http://dx.doi.org/10.1016/j.ejps.2003.10.019

Lamriben L., Graham J. B., Adams B. M., Hebert D. N. (2016): $\mathrm{N}$-Glycan-based ER molecular chaperone and protein quality control system: The calnexin binding cycle. Traffic 17, 308-326 http://dx.doi.org/10.1111/tra.12358

Li Y., Yuan H., Yang K., Xu W., Tang W., Li X. (2010): The structure and functions of P-glycoprotein. Curr. Med. Chem. 17, 786-800 http://dx.doi.org/10.2174/092986710790514507

Loo T. W., Clarke D. M. (1993): Functional consequences of proline mutations in the predicted transmembrane domain of P-glycoprotein. J. Biol. Chem. 268, 3143-3149

Ma H., Zhou H., Song X., Shi S., Zhang J., Jia L. (2015): Modification of sialylation is associated with multidrug resistance in human acute myeloid leukemia. Oncogene 34, 726-740 http://dx.doi.org/10.1038/onc.2014.7 
Madhavan S., Singh A. K., Maheshawari R. K. (2000): Tunicamycin enhances the anticellular activity of interferon by inhibiting G1/S phase progression in 3T3 cells. J. Interferon Cytokine Res. 20, 281-290 http://dx.doi.org/10.1089/107999000312414

Messingerova L., Imrichova D., Kavcova H., Turakova K., Breier A., Sulova Z. (2015a): Acute myeloid leukemia cells MOLM-13 and SKM-1 established for resistance by azacytidine are crossresistant to P-glycoprotein substrates. Toxicol. in Vitro 29, 1405-1415 http://dx.doi.org/10.1016/j.tiv.2015.05.011

Messingerova L., Jonasova A., Barancik M., Polekova L., Seres M., Gibalova L., Breier A., Sulova Z. (2015b): Lenalidomide treatment induced the normalization of marker protein levels in blood plasma of patients with 5q-myelodysplastic syndrome. Gen. Physiol. Biophys. 34, 399-406

Messingerova L., Imrichova D., Coculova M., Zelina M., Pavlikova L., Kavcova H., Seres M., Bohacova V., Lakatos B., Sulova Z., Breier A. (2016). Different mechanisms of drug resistance in myelodysplastic syndromes and acute myeloid leukemia. (Chapter 7). In: Myelodysplastic Syndromes. (Ed. Fusch O.) InTech Open Science, Open Mind, pp. 181-200 http://dx.doi.org/10.5772/63483

Michalak M., Groenendyk J., Szabo E., Gold L. I., Opas M. (2009): Calreticulin, a multi-process calcium-buffering chaperone of the endoplasmic reticulum. Biochem. J. 417, 651-666 http://dx.doi.org/10.1042/BJ20081847

Molnar J., Kars M. D., Gunduz U., Engi H., Schumacher U., Van Damme E. J., Peumans W. J., Makovitzky J., Gyemant N., Molnar P. (2009): Interaction of tomato lectin with ABC transporter in cancer cells: glycosylation confers functional conformation of P-gp. Acta Histochem. 111, 329-333 http://dx.doi.org/10.1016/j.acthis.2008.11.010

Morin M. J., Bernacki R. J. (1983): Biochemical effects and therapeutic potential of tunicamycin in murine L1210 leukemia. Cancer Res. 43, 1669-1674

Orlicky J., Sulova Z., Dovinova I., Fiala R., Zahradnikova A., Jr., Breier A. (2004): Functional fluo-3/AM assay on P-glycoprotein transport activity in L1210/VCR cells by confocal microscopy. Gen. Physiol. Biophys. 23, 357-366

Pallis M., Russell N. (2000): P-glycoprotein plays a drug-effluxindependent role in augmenting cell survival in acute myeloblastic leukemia and is associated with modulation of a sphingomyelin-ceramide apoptotic pathway. Blood 95, 2897-2904

Parfett C. L., Jamieson J. C., Wright J. A. (1983): Changes in cell surface glycoproteins on non-differentiating L6 rat myoblasts selected for resistance to concanavalin A. Exp. Cell. Res. 144, 405-415 http://dx.doi.org/10.1016/0014-4827(83)90420-2

Pastan I., Gottesman M. M., Ueda K., Lovelace E., Rutherford A. V., Willingham M. C. (1988): A retrovirus carrying an MDR1 cDNA confers multidrug resistance and polarized expression of P-glycoprotein in MDCK cells. Proc. Natl. Acad. Sci. U.S.A. 85, 4486-4490 http://dx.doi.org/10.1073/pnas.85.12.4486

Polekova L., Barancik M., Mrazova T., Pirker R., Wallner J., Sulova Z., Breier A. (1992): Adaptation of mouse leukemia cells L1210 to vincristine. Evidence for expression of P-glycoprotein. Neoplasma 39, 73-77
Ruefli A. A., Johnstone R. W. (2003): A role for P-glycoprotein in regulating cell growth and survival. Clinic. Applied Immunol. Rev. 4, 31-41 http://dx.doi.org/10.1016/S1529-1049(03)00005-9

Seres M., Ditte P., Breier A., Sulova Z. (2010): Effect of thapsigargin on P-glycoprotein-negative and P-glycoprotein-positive L1210 mouse leukaemia cells. Gen. Physiol. Biophys. 29, 396-401 http://dx.doi.org/10.4149/gpb_2010_04_396

Seres M., Cholujova D., Bubencikova T., Breier A., Sulova Z. (2011): Tunicamycin depresses P-glycoprotein glycosylation without an effect on its membrane localization and drug efflux activity in L1210 Cells. Int. J. Mol. Sci. 12, 7772-7784

http://dx.doi.org/10.3390/ijms12117772

Stavrovskaya A., Turkina A., Sedyakhina N., Stromskaya T., Zabotina T., Khoroshko N., Baryshnikov A. (1998): Prognostic value of P-glycoprotein and leukocyte differentiation antigens in chronic myeloid leukemia. Leuk. Lymphoma 28, 469-482 http://dx.doi.org/10.3109/10428199809058354

Sulova Z., Orlicky J., Fiala R., Dovinova I., Uhrik B., Seres M., Gibalova L., Breier A. (2005): Expression of P-glycoprotein in L1210 cells is linked with rise in sensitivity to Ca2+. Biochem. Biophys. Res. Commun. 335, 777-784 http://dx.doi.org/10.1016/j.bbrc.2005.07.144

Sulova Z., Mislovicova D., Gibalova L., Vajenerova Z., Polakova E., Uhrik B., Tylkova L., Kovarova A., Sedlak J., Breier A. (2009): Vincristine-induced overexpression of P-glycoprotein in L1210 cells is associated with remodeling of cell surface saccharides. J. Proteome Res. 8, 513-520 http://dx.doi.org/10.1021/pr8007094

Sulova Z., Ditte P., Kurucova T., Polakova E., Rogozanova K., Gibalova L., Seres M., Skvarkova L., Sedlak J., Pastorek J., Breier A. (2010): The presence of P-glycoprotein in L1210 cells directly induces down-regulation of cell surface saccharide targets of concanavalin A. Anticancer Res. 30, 3661-3668

Tainton K. M., Smyth M. J., Jackson J. T., Tanner J. E., Cerruti L., Jane S. M., Darcy P. K., Johnstone R. W. (2004): Mutational analysis of P-glycoprotein: suppression of caspase activation in the absence of ATP-dependent drug efflux. Cell. Death. Differ. 11, 1028-1037 http://dx.doi.org/10.1038/sj.cdd.4401440

Turakova K., Pavlikova L., Messingerova L., Lakatos B., Breier A., Sulova Z. (2015): Reduced UDP-glucose levels are associated with P-glycoprotein over-expression in L1210 cells and limit glucosylceramide synthase activity. Anticancer Res. 35, 2627-2634

Uhrik B., El-Saggan A. H., Seres M., Gibalova L., Breier A., Sulova Z. (2006): Structural differences between sensitive and resistant L1210 cells. Gen. Physiol. Biophys. 25, 427-438

Zhu X., Zeng Y., Lehrman M. A. (1992): Evidence that the hamster tunicamycin resistance gene encodes UDP-GlcNAc:dolichol phosphate $\mathrm{N}$-acetylglucosamine-1-phosphate transferase. J. Biol. Chem. 267, 8895-8902

Received: July 27, 2016

Final version accepted: August 26, 2016 